\title{
On Living a Long, Healthy, and Happy Life, Full of Love, and with no Regrets, until Our Last Breath
}

\author{
An interview with Alejandro R. Jadad
}

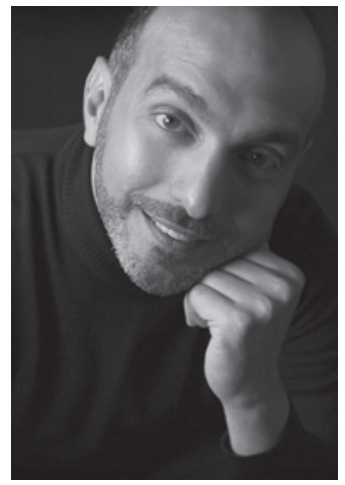

Photography by Jose Vergara
Professor Jadad is a physician, educator, researcher, and public advocate, whose mission is to help improving health and wellness for all, through human networks fueled by innovative uses of information and communication technologies. He has been called a 'human Internet', as his research and innovation work seeks to identify and connect the best minds, the best knowledge, and the best tools across traditional boundaries to eliminate unnecessary suffering. Such work focuses on a radical 'glocal' innovation model designed to improve the capacity of humans to imagine, to create, and to promote new and better approaches for living, healing, working, and learning across the world. Powered by social networks and other leading-edge telecommunication tools, his projects attempt to anticipate and respond to major public health threats (e.g., multiple chronic conditions, pandemics) through strong and sustainable international collaboration, and to enable the public (particularly young people) to shape the health system and society. Alejandro Jadad holds various positions at the University of Toronto and the University Health Network, all related to the creation and optimization of human health. He is the Canada Research Chair in eHealth Innovation; founder of the Centre for Global eHealth Innovation; Senior Scientist at the Centre for Health, Wellness and Cancer Survivorship (ELLICSR); and Professor at the Departments of Anesthesia, Faculty of Medicine, and at the Dalla Lana Faculty of Public Health. The interview was conducted by Professor Claus Vögele.

Why do we need a new understanding of the concept of health?

Because the official definition proposed by the World Health Organization (WHO) condemns most of us to be 'not healthy'. Such definition, which has remained unchanged for over 6 decades, refers to health as 'a state of complete physical, mental and social well-being and not just the absence of disease or infirmity ' [WHO, 1948].

Who could claim to have complete physical, mental, and social well-being? Practically nobody. Even a person who wears glasses feels a little stressed in preparation for an interview, or has dental cavities, could not claim to be healthy. Many had mentioned this over the years, but little had happened in terms of finding an alternative.

\section{KARGER}

Fax +497614520714

Information@Karger.com

www.karger.com (c) 2013 S. Karger GmbH, Freiburg

Accessible online at:

www.karger.com/ver
I pointed this out back in 2008, when we were celebrating the 60th anniversary of the WHO. As a result, that same year the British Medical Journal (BMJ) invited me to convene a global conversation about the meaning of the word [Jadad and O'Grady, 2008a,b]. This effort motivated the Health Council of the Netherlands and the Netherlands Organisation for Health Research and Development to support a 2-day invitational meeting in The Hague where 38 participants proposed a conceptualization of health as 'the ability to adapt and to self-manage' when facing physical, mental, and social challenges [Huber et al, 2011]. This applies to us as both individuals and members of a community. 
What are the implications of this new conceptualization for our current clinical practice?

It illustrates the limitations of the 'diagnose-and-fix' approach that still dominates most health care systems throughout the world, and helps us recognizing that such approach is of value only to a small fraction of people who face acute, curable conditions.

Once we view health through the lens of our ability to adapt and to self-manage, many new interesting possibilities emerge. A key possibility is the co-existence of health and disease; in other words, it is possible to be ill and healthy at the same time [Carel, 2008].

An important body of work suggests that most people, including seniors living with multiple chronic diseases, consider their health to be good, very good, or excellent. A Canadian survey [Terner et al., 2011] of over 3,000 people aged 65 years or older illustrates this point clearly, as it showed that $86 \%$ of those with one, $77 \%$ of those with 2 , and $51 \%$ of those with 3 or more diseases regarded their health to be good, very good, or excellent. These data are replicated innumerable times in quality of life studies that include self-assessments of health. In addition, a metaanalysis of 22 cohort studies revealed that individuals who rate their health as 'poor' have a two-fold higher mortality risk compared with those who consider their health as 'excellent' [DeSalvo et al., 2006]. An Australian study goes even further, by showing not only that most people (62\%) living with advanced incurable cancer consider their health to be good or better, but also that their self-assessments are the best predictors of their survival [Shadbolt et al., 2002].

Would you say that health has an important mental undercurrent? What role does wellness play in all of this? Is wellbeing out of the picture?

Health could be considered fundamentally as a mental phenomenon that could only be judged in the presence of a challenge. Because of its reactive nature, the reformulation of health as the ability to adapt and to self-manage opens the door for the concept of wellness as its proactive complement, which reflects our ability to fulfill our personal and collective human potential and to pursue a joyful life. Viewed through this lens, health and wellness, as complementary entities, would constitute the conceptual building blocks of well-being, which is a state, not an ability. These building blocks, which are already built into the word, contain its meaning: being well.

What is your view on the organization of traditional health care services, in particular regarding the rise in the prevalence of multimorbidity?

We are now paying the price for the dramatic increase in life expectancy that humans achieved in the 20th century.
There is a clear epidemic of chronic, incurable diseases, which now account for most of our morbidity and mortality worldwide. This epidemic has created yet another new phenomenon: a growing number of people are living with multiple chronic diseases. First studies show how multimorbidity may be already now the most prevalent chronic condition [Barnett et al., 2012]! When we live with multiple chronic diseases, we present challenges that are much more than the sum of the consequences of each individual condition [Jadad et al., 2010]. Our needs cannot be met by diagnostic tests, curative interventions, or health care services that are focused on individual organs (e.g., cardiology), systems (e.g., gastroenterology), or diseases (e.g., cancer). Instead, we require services that enable us to see people as a whole, that are responsive to our culture, and that are sensitive to our unique individual needs. We want responsible and integrated services that take into account our physical, mental, spiritual, and social needs. We want a sustainable support system that enables us to pursue a full life.

Multimorbidity reminds us that it is not enough to put more years into our lives, but that it is essential, and perhaps even more important, to put more life into our years [Jadad, 2012].

I have heard you talking about the need to prevent the preventable, to treat the treatable, and to cope with the inevitable. Could you please expand on this?

It is fascinating to realize that we do not have a gold standard for the health system, anywhere in the world. We cannot answer the question 'How healthy could we aspire to be if resources were not an issue?' We really do not know.

How much of what is preventable could we actually prevent? How much of what is curative could we really cure? How much of what we cannot prevent or cure could we view not only as inevitable, but also as a great source of meaning and purpose throughout our entire lives, until the last breath? What would it take to have a good death?

Any effort to answer these questions will invite us to open the door to other concepts, which are likely to be fundamental determinants and generators of health. Perhaps the 2 most important, and most neglected, are happiness and love. After all, is there any greater or more important challenge than to figure out how all of us could live long, healthy, and happy lives, full of love, and with no regrets, until our last breath [Jadad, 2013]?

Professor Jadad, thank you very much for this interview. 


\section{References}

Barnett K, Mercer SW, Norbury M, Watt G, Wyke S, Guthrie B: Epidemiology of multimorbidity and implications for health care, research, and medical education: a cross-sectional study. Lancet 2012; 380:37-43.

Carel H: Illness. Durham, Acumen Publishing, 2008.

DeSalvo KB, Bloser N, Reynolds K, He J, Muntner P: Mortality prediction with a single general self-rated health question: a meta-analysis. J Gen Intern Med 2006;21:267-275.

- Huber M, Knottnerus JA, Green L, Horst H, Jadad AR, Kromhout D, Leonard B, Lorig K, Loureiro MI, Meer JW, Schnabel P, Smith R, Weel C, Smid H: How should we define health? BMJ 2011;343: d4163.

Jadad AR: Do we really know what we mean by 'health'? Opening keynote lecture, Transform Symposium, Mayo Clinic, September 8, 2012 www.youtube.com/ watch? $v=i K J w P k G S y F I$ (accessed on 05.11.13)

Jadad AR: Dying healthy and happy: the greatest challenge of our time. Keynote at the 2013 Help the Hospices Conference, Bournemouth, UK, October 23, 2013. www.helpthehospices.org.uk/our-services/education-training/help-the-hospicesconference-2013/dying-healthy-and-happy-the-most-important-challenge-of-ourtime (accessed on 05.11.13).

Jadad AR, O'Grady L: How should health be defined? BMJ 2008a;337:a2900.

Jadad AR, O'Grady L: A global conversation on defining health. BMJ Group Blogs, December 10, 2008b. http://blogs.bmj.com/bmj/2008/12/10/alex-jadad-ondefining-health (accessed on 05.11.13).

Jadad AR, Cabrera A, Martos F, Smith R, Lyons RF: When People Live with Multiple Chronic Diseases: A Collaborative Approach to an Emerging Global Challenge. Granada, Andalusian School of Public Health, 2010. www.opimec.org/ media/files/BOOK_OPIMEC_100818.pdf (accessed on 05.11.13).

-Shadbolt B, Barresi J, Craft P: Self-rated health as a predictor of survival among patients with advanced cancer. J Clin Oncol 2002;20:2514-2519.

- Terner M, Reason B, McKeag AM, Tipper B, Webster G: Chronic conditions more than age drive health system use in Canadian seniors. Healthc Q 2011; 14:19-22.

Word Health Organization: WHO definition of health. www.who.int/about/definition/ en/print.html (accessed on 05.11.13). 